Accounting Profession Journal (ApaJi), Vol. 2 No 2, Bulan Juli 2020

\title{
CORPORATE SOCIAL RESPONSIBILTY (CSR) BERKEADILAN SOSIAL Dadek Nandemar ${ }^{1}$, Dr. H. Amiruddin, M.Si, Ak, $\mathrm{CA}^{2}$ \\ ${ }^{1,2}$ Universitas Hasanuddin Makassar dnandemar@hotmail.com
}

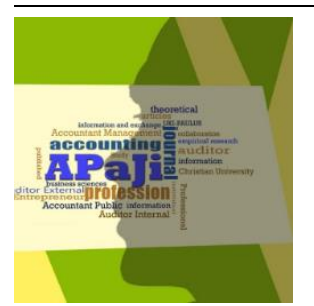

e-ISSN 2686-0058 p-ISSN 2715-7695

$\underline{\text { Informasi Artikel }}$ Tanggal masuk 11 April 2020 Tanggal revisi 28 Mei 2020

Tanggal diterima 06 Juli 2020

Kata Kunci: social responsibility ${ }^{l}$ Pancasila $^{2}$ fair $^{3}$ Corporate Social Responsibility $(\mathrm{CSR})^{4}$
Abstract: Conflicts that occur between indigenous peoples and corporations are a form of community rejection of capitalism that rides corporations to make maximum profits without regard to community rights. People who lived peacefully before a corporation opened a business by acquiring customary forests as a source of livelihood for people who lost their livelihoods. Corporate Social Responsibility (CSR) is expected as a medium for resolving conflicts that occur which is certainly adjusted to the philosophy of our country, namely Pancasila and the 1945 Constitution. The research approach uses critical studies that aim to uncover the meaning of the phenomenon of conflict that occurs. Then the authors reconstruct by offering a form of CSR that is Pancasila. The concept of Pancasila justice as a basis for the implementation of the triple bottom line with aspects of profit, people, and planet $(3 P)$, which is not only profit oriented, but also must be able to provide justice to the people as well as fair and preserve the environment (planet). Thus, bringing justice for indigenous peoples who have lost their livelihoods from the forest are replaced by commensurate sources of livelihood so that the community can coexist harmoniously with the company, which in turn will create a prosperous, just and prosperous society.

Abstrak: Konflik yang terjadi antara masyarakat adat dengan korporasi adalah bentuk dari penolakan masyarakat terhadap kapitalisme yang menunggangi korporasi untuk mengeruk keuntungan yang sebesar-besarnya tanpa memperhatikan hak masyarakat. Masyarakat yang hidup tenang sebelum ada korporasi yang membuka usaha dengan mengakusisi hutan adat sebagai sumber penghidupan masyarakat kehilangan sumber mata pencahariannya. Corporate Social Responsibility CSR) diharapkan sebagai media untuk menyelesaikan konflik yang terjadi yang tentunya disesuaikan dengan dengan filosofis negara kita, yaitu Pancasila dan UUD 1945. Pendekatan penelitian mengunakan studi kritis yang bertujuan untuk mengungkap makna fenomena konflik yang terjadi. Kemudian penulis merekonstruksi dengan menawarkan bentuk CSR yang pancasilais. Konsep keadilan Pancasila sebagai dasar penerapan triple bottom line dengan aspek profit, people, dan planet (3P), yakni bukan hanya keuntungan (Profit) yang diorientasikan, namun juga harus mampu memberikan keadilan kepada masyarakat (People) serta adil dan menjaga kelestarian lingkungan (Planet). Sehingga membawa keadilan bagi masyarakat adat yang telah kehilangan penghidupannya dari hutan digantikan sumber penghidupan yang sepadan sehingga masyarakat dapat hidup berdampingan secara harmonis dengan perusahaan, di mana nantinya akan meujudkan masyarakat sejahtera, adil dan makmur.

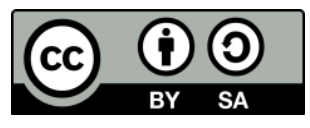


Accounting Profession Journal (ApaJi), Vol. 2 No 2, Bulan Juli 2020

\section{PENDAHULUAN}

Pengaturan pengelolaan sumber daya alam di Indonesia merujuk pada Pasal 33 ayat (3) UUD RI 1945 yaitu "Bumi dan air dan kekayaan alam yang terkandung di dalamnya dikuasai oleh negara dan dipergunakan untuk sebesar-besar kemakmuran rakyat”. Frasa tentang sebesarbesar kemakmuran rakyat memerlukan implementasi yang lebih konkret, salah satu bapak pendiri bangsa kita yaitu Mohammad Hatta pernah menyampaikan bahwa "kemakmuran rakyat-sentris" yaitu mendahulukan tercapainya kemakmuran rakyat banyak. Segala eksplorasi dan eksploitasi segala kekayaan alam kita, minyak, gas bumi, nikel, timah dan sebagainya; di atas pantai maupun lepas-pantai boleh saja dikerjakan oleh swasta, kalau Negara belum berdaya sepenuhnya; namun kesemuanya itu harus "dipergunakan sebesar-besar kemakmuran rakyat" dan sekali-kali tidak untuk kemakmuran dan kemewahan minoritas elita atasan dan berkuasa".

Dalam penjelasan Pasal 33 ditegaskan bahwa perusahaan-perusahaan yang penting bagi negara dan menguasai hajat hidup orang banyak harus berada di tangan negara. Akan tetapi, dalam prakteknya pemerintah menyerahkan kepada perusahaan swasta, untuk mengelola kekayaan negara. Dalam sistem perekonomian kapitalis yang dijalankan di negara Indonesia saat ini, korporasi adalah organisasi berorientasi laba. Akumulasi kapital dan maksimalisasi laba adalah esensi keberadaannya. Orientasi perusahaan atas laba acapkali menimbulkan permasalahan dengan masyarakat sekitarnya, misalnya beberapa kasus perusahaan pertambangan dan perkebunan mengalami konflik dengan masyarakat setempat terkait hak adat dalam wilayah tambang dan kebun. Masyarakat yang memanfaatkan hutan untuk memenuhi kebutuhan sehari-hari dengan berburu dan memanfaatkan hasil lainnya, sebagai hak adatnya, telah kehilangan hutan sebagai mata pencaharian mereka.

Smith (2002) menemukan pentingnya tekanan terhadap korporasi untuk menerapkan Tanggung Jawab Sosial Korporasi. Korporasi/perusahaan harus memperluas makna Tanggung Jawab Korporasi sesuai dengan ideologi Bangsa yang kita anut, yaitu Pancasila dan UndangUndang Dasar 1945, hal ini termasuk pengakuan dan penghargaan terhadap terhadap hak-hak asasi manusia khususnya hak-hak masyarakat hukum adat di Indonesia. Dari berbagai kasuskasus konflik antara korporasi dengan masyarakat hukum adat, kurangnya rekognisi dan respek terhadap hak-hak masyarakat hukum adat atas sumber-sumber alam sekitar masyarakat sebagai diduga sebagai factor penyebab. Walaupun rekognisi hak-hak masyarakat hukum adat atas sumber-sumber agraria oleh korporasi telah dipraktikkan oleh korporasi perkebunan dan 
pertambangan di Indonesia, namun pada dasarnya hal ini timbul akibat dari tekanan-tekanan masyarakat hukum adat ketimbang inisiatif dari perusahaan.

Masyarakat adat yang hidup tenang, memanfaatkan hutan yang ada dengan adanya korporasi kehilangan ketengan kenyamanan hidup yang di alami yang tentunya ini dirasakan tidak adil oleh mereka. Sementara itu perusahaan yang merasa telah memenuhi segala kewajibannya untuk membuka usaha bukanlah penyebab dari kesengsaraan masyarakat. Pemerintah dianggap gagal mewujudkan kesejahteraan bagi masyarakat. Corporate social responsibility (CSR) merupakan media untuk dapat menyelesaikan permasalahan antara perusahaan dengan masyarakat dan pemerintah. Melalui nilai-nilai Pancasila khususnya Sila Kelima, Keadilan Sosial yang ditanamkan dalam konsep triple bottom line akan membawa kesejahteraan/kemakmuran bagi masayrakat.

\section{METODE}

Paradigma dan Metode Analisis Penelitian Paradigma dalam penelitian merupakan suatu rerangka berpikir yang dapat menjelaskan bagaimana cara pandang peneliti terhadap fakta kehidupan sosial dan perlakuan peneliti terhadap sebuah ilmu atau teori (Juliandi dan Manurung, 2014; Yusuf, 2016). Paradigma penelitian juga menjelaskan bagaimana peneliti memahami suatu masalah, kriteria pengujian sebagai landasan untuk menjawab masalah penelitian. Penelitian ini menggunakan paradigma kualitatif atau pendekatan naturalistik atau konstruktifis (Juliandi dan Manurung, 2014; Setyosari, 2016). Paradigma ini meliputi pendekatan kritis, interpretif dan post modern.

Studi kritis merupakan salah satu pendekatan dalam paradigma kualitatif disamping pendekatan interpretif dan postmodernis (Chua, 1986; Burrel dan Morgan, 1979). Teori kritis muncul pada saat adanya pemikiran-pemikiran yang sangat kritis terhadap pemikiran Karl Mark dan penerusnya. Pemikiran-pemikiran ini pada gilirannya muncul menjadi sebuah mahzab yang dikenal dengan mahzab Frankfurt dimana merupakan perkembangan lebih lanjut dari Marxisme barat. Studi kritis berupaya mencari makna di balik yang empiris, dan menolak adanya konsep value free. Studi kritis mempunyai komitmen yang tinggi kepada tata sosial yang lebih adil. Asumsi dasarnya adalah bahwa ilmu sosial bukan sekedar memahami ketidakadilan dalam distribusi kekuasaan dan distribusi resources, melainkan berupaya untuk membantu 
menciptakan kesamaan dan emansipasi dalam kehidupan. Studi kritis ini memiliki keterikatan moral untuk mengkritik status quo dan membangun masyarakat yang lebih adil (Raco, 2011).

Tujuan pendekatan studi kritis adalah menghilangkan berbagai bentuk dominasi dan mendorong kebebasan, keadilan dan persamaan. Teori ini menggunakan metode reflektif dengan cara mengkritik secara terus-menerus terhadap tatanan kehidupan yang cenderung tidak kondusif bagi pencapaian kebebasan, keadilan, dan persamaan. Studi kritis dalam penelitian ini tidak hanya untuk memaparkan kondisi riil sosial masyarakat namun juga berusaha merubah secara perlahan.

Pada tulisan ini, Pancasila akan berperan sebagai nilai lain yang akan diinternalisasikan kedalam konsep corporate social responsibility (CSR) dalam triple bottom line-nya. Upaya memanifestasi atau memasukkan nilai lain ke dalam CSR tersebut dapat disebut sebagai upaya dekonstruksi yang dikenalkan oleh Derrida (Triyuwono, 2001: 6; dan O’Donnel, 2009: 56-57) $[38,39]$. Proses ini kemudian akan menjadi konsep agar CSR lebih adil dan dapat membawa kemakmuran bersama dengan masyarakat. Integrasi Pancasila ke dalam konsep entitas ekonomi dan konsep triple bottom line berdasarkan sila ke-5 yaitu Keadilan Sosial. Triple bottom line menurut Elkington, terdiri dari Profit (laba), People (orang), dan Planet (Lingkungan) harus didasari sifat adil, untuk mewujudkan kemakmuran rakyat, sesuai semangant Pasal 33 UUD 1945.

\section{PEMBAHASAN}

\section{Tanah dan Masyarakat Adat}

Tanah dan masyarakat adat mempunyai hubungan erat satu dengan yang lainnya. Bagi masyarakat adat tanah memiliki kedudukan yang sangat penting, karena sifatnya: merupakan satu-satunya benda kekayaan yang meskipun mengalami keadaan yang bagaimana pun juga bersifat tetap dalam keadaannya bahkan kadang-kadang menjadi lebih menguntungkan. Selain itu dikarenakan adanya fakta bahwa tanah merupakan tempat tinggal masyarakat adat, memberikan penghidupan kepada masyarakat adat, tempat dimana masyarakat adat yang meninggal dunia di kebumikan dan tempat tinggal para leluhur dari masyarakat adat. Makna kedudukan tanah dalam hukum adat memberi arti bahwa adanya hubungan antara masyarakat hukum adat dengan tanahnya menciptakan hak kepada masyarakat untuk menggunakan tanah bagi keuntungan masyarakat tersebut. Tanah adat meliputi semua tanah di lingkungan 
masyarakat adat yang dianggap sebagai sumber hak atas tanah lainnya dan dapat dipunyai oleh seluruh anggota masyarakat adat setempat.

Van Vollenhoven memperkenalkan istilah "Beschikkingsrecht" yang diterjemahkan sebagai "Hak Ulayat" untuk hubungan hukum, sejak itu istilahnya diterima oleh umum, walaupun istilah-istilah disetiap daerah berbeda-beda seperti: "Wewengkon" (Jawa), "Prabumian" (Bali), "Pawatasan” (Kalimantan), dan "Limpo" (Sulawesi Selatan). Salah satu slogan tradisional atas tanah (Batak Toba) "Arga do bona ni pinasa" yang mengartikan Tanah leluhur bernilai tinggi. namun tetap mempunyai arti yang sama yaitu tanah yang merupakan wilayah yang dikuasai oleh warga persekutuan masyarakat adat (Simanjuntak, 2015).

Pengertian hak ulayat secara umum utamanya berkenaan dengan hubungan hukum antara masyarakat hukum adat dengan tanah dalam lingkungan wilayahnya. Dalam pengertian hukum merupakan serangkaian wewenang dan kewajiban sesuatu masyarakat hukum adat tertentu atas suatu wilayah tertentu yang merupakan ulayatnya, sebagai "lebensraum" para warganya untuk mengambil manfaat dari sumber daya alam, termasuk tanah, perairan, tanaman dan binatang dalam wilayahnya yang menjadi sumber kehidupan dan mata pencariannya. Wewenang dan kewajiban tersebut timbul dari hubungan secara lahiriah dan batiniah turun temurun antara masyarakat adat tersebut dengan wilayah yang bersangkutan. Hubungan ini selain merupakan hubungan lahiriah, juga merupakan hubungan batiniah yang bersifat religiomagisch. Yaitu berdasarkan kepercayaan para warga masyarakat hukum adat yang bersangkutan bahwa wilayah tersebut adalah pemberian suatu kekuatan yang gaib atau peninggalan nenek moyang yang diperuntukkan bagi kelangsungan hidup dan penghidupannya sepanjang masa. Pada dasarnya hubungan itu merupakan hubungan abadi.

Adanya pembangunan infrastruktur, pertanian maupun perkebunan skala besar, minyak dan gas bumi menimbulkan konflik dengan masyarakat setempat. Pembangunan tersebut memerlukan tanah, akan tetapi proses pembangunannya kurang mempertimbangkan hak masyarakat yang ada. Berbagai kasus sengketa tanah yang timbul dalam pemanfaatan tanah adalah terjadi ketika konflik kepentingan antara masyarakat hukum adat yang mempertahankan hak adat atas tanah dengan investor atau pihak swasta (pemilik modal/investor besar) yang mendapat konsesi pengusahaan hutan, perkebunan, pertambangan (pertambangan minyak dan gas bumi). Masyarakat merasa terpinggirkan, investor atau pengusaha hanya memanfaatkan tanah tanpa pernah memikirkan nasib masyarakat adat sekitarnya. Kejadian ini cukup dominan 
di daerah-daerah kaya mineral, konflik terus terjadi antara masyarakat adat dan pemerintah atau perusahaan swasta pemegang konsesi, seperti yang pernah di kampung harapan dan Freeport Papua, Waykambas (Lampung), dan Bukit Betabuh Sungai Indah di Riau, kawasan Labo di kabupaten Nagekeo, Nusa Tenggara Timur, Desa Parbuluhan Sumatera Utara mengakui bahwa tanah yang mereka garap adalah tanah ulayat milik masyarakat adat, dan mereka hanya penggarap. Ini mengakibatkan marjinalisasi masyarakat atas tanah adatnya sendiri.

\section{Ekonomi Pancasila Rasa Kapitalis}

Sistem perekonomian Indonesia terpengaruh oleh sistem kapitalis yang berasal dari dunia barat, dengan ciri khasnya antara lain adanya korporasi yaitu organisasi yang berorientasi laba. Akumulasi kapital dan maksimalisasi laba adalah esensi keberadaannya. Hal yang terjadi adalah seperti yang diungkapkan oleh ahli-ahli Marxis, akumulasi kapital dan maksimalisasi laba dua hal yang saling berkaitan karena akumulasi kapital yang dilakukan berdasarkan prinsip maksimalisasi laba (Brewer, 1999:55-119; Amin, 1988; Sweezy: 57-81).

Kapitalisme yaitu paham yang meyakini pemilik modal dapat melakukan usahanya untuk memperoleh keuntungan sebesar-besarnya, untuk prinsip tersebut, maka pemerintah tidak boleh melakukan intervensi pasar untuk memperoleh keuntungan bersama. Periode tahun 1877 sampai tahun 1932 pada dasarnya menandai perkembangan kapitalisme modern di Amerika Serikat, penataan kembali aktor dan institusi ekonomi dalam sistem pasar yang lebih bersifat industri, lebih terorganisir, dan lebih korporat. Kapitalisme adalah sistem tiga tingkat, pasar menempati tingkat pertama, di mana persaingan berlangsung; Organisasi kelembagaan yang mendukung pasar tersebut adalah yang kedua; dan otoritas politik yang mengelola sistem adalah yang ketiga. Sementara pasar mengkoordinasikan penawaran dan permintaan dengan bantuan tangan tak terlihat. Dalam perspektif yang lebih luas, pemerintah memiliki dua peran yang berbeda, satu untuk mengelola kerangka kelembagaan yang ada, termasuk penyediaan infrastruktur dan administrasi undang-undang dan peraturan, dan yang kedua untuk memobilisasi kekuatan politik untuk mewujudkan modernisasi kerangka kerja tersebut sebagai keadaan.

Ekonomi kapitalis mulai diperkenalkan dan dijadikan tatanan global yang kemudian diikuti oleh negara-negara di dunia. Inggris dan Amerika yang semenjak terjadi revolusi konservatif di masa Reagen dan Thacher dan menjadi pelopor perubahan tatanan global tersebut 
menuju prinsip liberalisme. Lembaga multilateral, seperti Bank Dunia, IMF, serta bank-bank pembangunan regional, seperti Asian Development Bank (ADB) dijadikan sebagai kepanjangan tangan untuk keperluan transformasi tersebut. Negara-negara yang sedang berkembang yang memperoleh dukungan pinjaman dana dari Lembaga-lembaga tersebut harus terlebih dahulu menandatangani sebuah perjanjian yang memuat prinsip-prinsip dikenal dengan the Washington Consensus.

Faktor-faktor yang mendorong munculnya liberalisme sebagai awal masuknya kapitalisme, yang pertama yaitu lahirnya perusahaan multinasional corporation (MNC) sebagai sebuah kekuatan yang nyata, bahkan memiliki kekayaan yang lebih besar dari pada negaranegara kecil yang ada di dunia. Mereka ini rata-rata memiliki kantor pusat di negara-negara maju (Amerika Serikat, Uni Eropa, Kanada, Jepang, Australia) memanfaatkan semua fasilitas infrastruktur milik negara-negara tersebut. Akan tetapi langkah mereka di bimbing bukan oleh sebuah nasionalisme, melainkan semata-mata oleh insting mengeruk laba di mana pun kesempatan itu berada. Pada saat kritis, mereka bisa mengubah modal yang begitu besar yang mereka punya menjadi bargaining power, dan memaksa pihak yang lain untuk takluk, bahkan negara asal mereka (home country).

Meskipun dalam UUD 1945 Pasal 33 dan penjelasannya singkat, namun ideologi yang terkandung didalamnya memenuhi syarat sebagai suatu sistem ekonomi, karena berangkat dari asas Pancasila khususnya untuk mewujudkan sila ke 5 (lima), yaitu keadilan sosial bagi seluruh rakyat Indonesia. Kata "sosial” dalam prinsip kelima dari Pancasila memiliki dua pengertian. Pertama, menunjuk ke dimensi sosial keadilan dalam kehidupan nasional. Keadilan sosial harus melibatkan seluruh rakyat Indonesia dan harus diterapkan dalam setiap bidang kehidupan. Ini berarti bahwa keadilan sosial tidak menjadi milik hanya satu kelompok dari orang-orang tetapi bagi seluruh masyarakat Indonesia. Kedua, mengacu pada "masyarakat", yang dapat menjadi “subjek” dan “objek” keadilan. Demi kesejahteraan nasional, rasa keadilan sosial mewajibkan masyarakat dan pemerintah untuk membagi barang dan jasa secara adil. Dalam proses ini yang lemah dan marginal harus dilindungi dan dibantu untuk mencapai derajat yang sah pembangunan manusia. 
Accounting Profession Journal (ApaJi), Vol. 2 No 2, Bulan Juli 2020

\section{Korporasi Berorientasi Laba}

Seperti di negara yang lain, di Indonesia prestasi korporasi dinilai oleh segala pihak berdasarkan besaran laba yang berhasil dihasilkannya. Inilah yang disebut oleh Weber sebagai etika kapitalisme (Weber 1930: 47-78) yang menimbulkan perilaku pemaksimalan laba (Henderson dalam King, 2001). Laba dapa meningkatkan kesejahteraan menurut Adam Smith. Kemudian ahli ekonomi klasik lainnya mengikuti konsep laba dari Smith dan mengaitkan konseptualisasi pada praktik bisnis. Fisher, sebagaimana dikutip oleh Belkaoui (2000: 129) mendefinisikan laba ekonomi sebagai rangkaian kejadian yang berhubungan dengan kondisi yang berbeda, yaitu laba kepuasan batin, laba sesungguhnya dan laba uang.

Laba kepuasan batin adalah laba yang muncul dari konsumsi seseorang sesungguhnya atas barang dan jasa yang menghasilkan kesenangan batin dan kepuasan atas keinginan di mana laba ini tidak diukur secara langsung, tetapi dapat diproksikan oleh laba sesungguhnya. Laba sesungguhnya adalah pernyataan atas kejadian yang meningkatkan kesenangan batin, di mana ukuran laba ini adalah biaya hidup. Untuk laba uang, diartikan bahwa laba ini menunjukkan semua uang yang diterima yang digunakan untuk konsumsi guna membiayai hidup.

Laba akuntansi mempunyai beberapa kelemahan, karena laba akuntansi belum didefinisikan secara semantik dan jelas sehingga laba tersebut hanya bermakna secara intuitif dan ekonomik. Penyajian dan pengukuran laba juga masih difokuskan pada pemegang saham biasa sehingga tidak ada dasar teoritis jangka panjang untuk perhitungan dan penyajian laba akuntansi. Prinsip akuntansi berterima umum (PABU) sebagai pedoman pengukuran laba juga masih memberi peluang untuk terjadinya inkonsistensi antar perusahaan. Laba akuntansi secara umum juga belum dapat memperhitungkan pengaruh perubahan daya beli dan harga karena hanya didasarkan pada konsep biaya historis. Dalam menilai kinerja perusahaan secara keseluruhan, investor dan kreditor masih memandang informasi lain dan tidak hanya berpegang pada laba akuntansi saja sehingga ketepatan laba akuntansi belum menjadi tuntutan yang mendesak.

Motivasi mencari laba menjauhkan korporasi dengan lingkungan sekitarnya. Corporate Social Responsibility (CSR), diterjemahkan dalam tulisan ini sebagai Tanggung Jawab Sosial Korporasi, merupakan suatu inovasi kebijakan untuk tata kelola korporasi yang baik tidak hanya internal korporasi malainkan juga hubungan antara korporasi dengan masyarakat. Konsep dan kebijakan Tanggung Jawab Sosial Korporasi adalah usaha untuk mengendalikan 
Accounting Profession Journal (ApaJi), Vol. 2 No 2, Bulan Juli 2020

atau menjinakkan semangat kapitalisme, menggunakan konsep Henderson (dalam King, 2003) itu adalah usaha untuk mengondisikan korporasi melakukan lebih dari pencarian laba. Dengan konsep ini, kinerja korporasi dan para manajernya tidak lagi hanya dinilai dari parameter etika kapitalisme, melainkan juga dari sudut tanggung jawab etika sosial.

\section{Corporate Social Responsibiliy (CSR)}

Konsep social sustainability muncul sebagai kelanjutan konsep economic sustainability dan environmental sustainability yang telah dicetuskan sebelumnya. Konsep ini muncul dalam pertemuan di Johannesberg pada tahun 2002 yang dilatarbelakangi oleh alasan-alasan yaitu konsep economic sustainability dan environmental sustainability yang dikembangkan sebelumnya belum dapat mengangkat kesejahteraan komunitas di negara-negara di dunia serta perlunya suatu tatanan aturan untuk menyeimbangkan kesejahteraan pembangunan baik di negara-negara selatan maupun negara-negara utara. Dengan latar belakang tersebut dirumuskan suatu visi yang sama dalam dunia usaha yang makin mengglobal dan mengarah pada liberalisasi untuk mewujudkan kebersamaan aturan bagi tingkat kesejahteraan umat manusia yaitu konsep social sustainability. Dalam perkembangan selanjutnya ketiga konsep ini menjadi patokan bagi perusahaan untuk melaksanakan tanggung jawab sosial yang kita kenal dengan konsep corporate social responsibility (CSR). Konsep ini merupakan jawaban, tentang topik tanggung jawab sosial perusahaan yang telah menjadi perdebatan selama beberapa dekade terakhir tentang hubungan yang ideal antara bisnis dan masyarakat (Klonoski 1991).

Kemunculan teori triple bottom-line (TBL) business yang dicetuskan oleh Elkington (1993, 2001) melengkapi konsep corporate social responsibility (CSR). Dengan menganalisis hubungan antara masyarakat (people), lingkungan (planet), dan bisnis (profit) dalam suatu bentuk segitiga. Elkington menganggap bahwa yang menduduki pilar utama dalam suatu bisnis adalah lingkungan dan pilar kedua adalah masyarakat. Elkington menyatakan bila perilaku bisnis tidak ikut serta dalam memelihara lingkungan dan masyarakat yang telah menjadi bottom-line dalam bisnis atau dengan kata lain apabila lingkungan dan masyarakat sampai terdegrasi atau mengalami krisis, maka laba perusahaan dan keberlanjutan usaha akan menghadapi masalah yang serius. Untuk mempertahankan keberlanjutan bisnis, perusahaan perlu memadukan capaian tujuan sosial dan lingkungan dalam tujuan ekonomi. 
Elkington (1997, 2001) menjelaskan ideologi bisnis mengedepankan pencapaian laba, menciptakan "korporasi belalang" dan "korporasi ulat" dalam jumlah yang besar yang sering melakukan eksploitasi serta merusak lingkungan, dan menimbulkan berbagai dampak degeneratif terhadap lingkungan dan masyarakat. Tidak sedikit korporasi yang memiliki perilaku tidak etis yang akhirnya tidak bisa menjaga kelangsungan hidup usahanya. Elkington menyatakan bahwa apabila menginginkan bisnisnya bisa tumbuh secara berkelanjutan, para pemilik modal harus menjadikan perusahaan mereka sebagai "korporasi lebah madu" atau "korporasi kupu-kupu". Dua jenis korporasi tersebut memiliki perilaku bisnis yang akan memberikan dampak regeneratif kepada lingkungan dan masyarakat yang akan menghasilkan return secara berkelanjutan kepada perusahaan.

Dukungan terhadap pemikiran Elkington datang dari banyak kalangan (Benn \& Bolton, 2011). Salah satunya datang dari Perserikatan Bangsa-Bangsa (PBB) yang menginisiasi pembentukan Global Compact pada Tahun 2001 dan Global Reporting Initiatives (GRI) pada 1999. Kepedulian pelaku bisnis, lembaga-lembaga internasional, pemerintah, dan korporasi global ataupun nasional, dalam satu dekade terakhir, terhadap isu-isu CSR juga semakin meningkat. Hal ini menandakan bahwa usulan "triple bottom-line business" Elkington merupakan usulan yang logis serta bermanfaat untuk keberlanjutan korporasi dalam jangka panjang. CSR dianggap sebagai komitmen perusahaan untuk memiliki tanggung jawab secara legal, ekonomik, sukarela, dan etis terhadap berbagai dampak yang diakibatkan dari aktivitas ekonomi yang telah dilakukan terhadap lingkungan dan komunitas masyarakat. Di samping itu, dengan program CSR perusahaan secara proaktif melakukan berbagai upaya berkelanjutan untuk mencegah terjadinya berbagai dampak negatif atau berbagai risiko dari aktivitas ekonomi yang telah dilakukan perusahaan terhadap lingkungan dan masyarakat, dan meningkatkan kualitas lingkungan dan sosial yang merupakan stakeholder-nya sebagai wujud cinta korporasi terhadap masyarakat dan lingkungannya. Batasan CSR tidak hanya sebesar tanggung jawab reaktif, sebagai akibat dari perusahaan yang telah menimbulkan dampak-dampak negatif, tetapi juga harus bertanggung jawab secara interaktif dan proaktif yaitu merumuskan berbagai program dan upaya yang berkesinambungan untuk mencegah berbagai risiko atau dampak negatif dalam kegiatan ekonomi terhadap lingkungan dan masyarakat. 


\section{CSR Yang Adil Menuju Masyarakat Sejahtera}

Rekonstruksi CSR yang sesuai dengan "karakteristik keindonesiaan” atau nilai-nilai Bangsa Indonesia harus berpedoman pada nilai-nilai Pancasila khususnya sila ke 5 (lima) yaitu Keadilan Sosial Bagi Seluruh Rakyat Indonesia, dan merupakan implementasi konkret dari spirit Pasal 33 Undang-Undang Dasar 1945, yaitu untuk mencapai "Bumi dan air dan kekayaan yang terkandung ddalamnya dikuasai oleh negara dan dipergunakan untuk sebesar-besar kemakmuran rakyat”. Nilai-nilai Pancasila dan Pasal 33 Undang-Undang Dasar 1945 itu belum dijadikan landasan secara optimal bagi pembentukan model penyelenggaraan CSR di Indonesia. Kecenderungan nilai-nilai Pancasila dan Pasal 33 Undang-Undang Dasar 1945 yang belum dijadikan landasan, menimbulkan pertanyaan atas CSR, terutama apabila dikaitkan dengan masalah kemiskinan yang masih dialami oleh sebagian masyarakat. Sudah sebandingkah dengan hasil keuntungan yang berhasil dihisap oleh korporasi? (Eko Prasodjo, 2006: 9-10). Belum adanya kejelasan rumusan mengenai konsep CSR, sehingga pada tahap praktik di lapangan justru menimbulkan perbedaan penafsiran mengenai sifat dari CSR itu sendiri.

Rekonstruksi CSR dengan konsep triple bottom line, namun disesuaikan dengan nilai keadilan dari pancasila dengan tujuan mewujudkan kesejahteraan masyarakat sesuai UUD 1945, dapat dilihat pada gambar berikut.

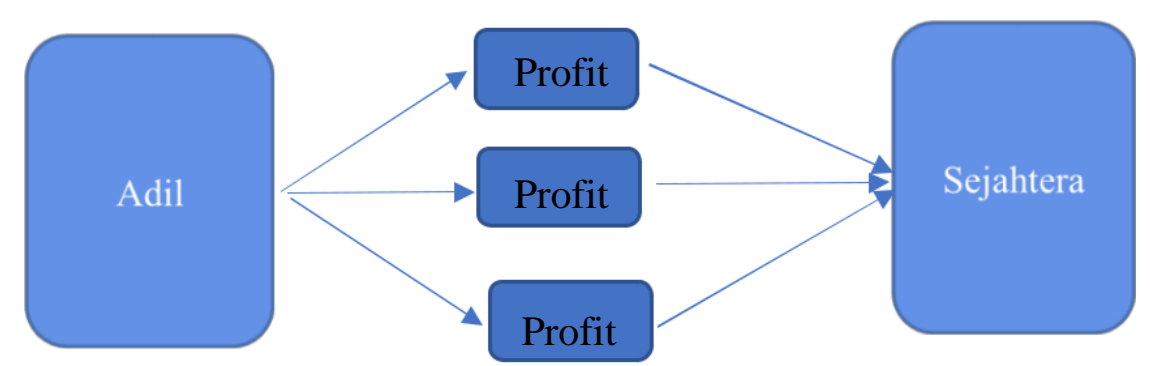

Gambar: Konsep CSR, Triple Bottom Line berfalsafah Pancasila

Falsafah negara yaitu Pancasila yang disusun dengan "Hati" telah membentuk Lima Sila yang saling mendukung untuk menciptakan kemakmuran di Negeri ini. Draft pertama dari flosof Pancasila dirumuskan oleh Sukarno pada tanggal 1 Juni 1945. Sukarno selalu menyatakan bahwa Pancasila adalah filosof asli asal Indonesia, yang ditemukan dari tradisi filsafat mengambil akar dalam sejarah Indonesia, termasuk tradisi adat filosofis, India - Hindu, 
Barat - Kristen, dan tradisi Arab - Islam. 'Ketuhanan', awalnya adat, sedangkan 'Kemanusiaan' terinspirasi oleh konsep Hindu Tat Twam Asi, konsep Islam fardhukifayah, dan konsep Kristen Hebs U naasten lief gelijk U Zelve, Allah boven alles. Sebenarnya "Sila" yang pertama Soekarno adalah "Negara Kebangsaan" ("Negara Nasional"/Nasionalisme”) yang kemudian menjadi "Sila" ketiga, "Persatuan", "Sila" ketiga dari Sukarno menjadi Sila keempat Piagam Jakarta/Pembukaan Konstitusi Indonesia dan Sila kelima Sukarno menjadi Sila pertama Piagam Jakarta dan Pembukaan Konstitusi. (Saafrudin Bahar et al., 1995 dan Kusuma, 2004). Akhirnya menjelaskan bahwa 'Keadilan sosial' terinspirasi oleh konsep Jawa Ratu Adil, seorang penguasa Jawa yang diramalkan oleh Joyoboyo yang membebaskan orang-orang dari segala macam penindasan. Konsep keadilan sosial telah menjadi salah satu pemikiran filosofis presiden Soekarno: "Keadilan sosial ialah suatu masyarakat atau sifat suatu masyarakat adil dan makmur, berbahagia buat semua orang, tidak ada penghinaan, tidak ada penindasan, tidak ada penghisapan".

Tampak sekali bahwa Soekarno sangat memprioritaskan nilai keadilan dan menjunjung tinggi nilai hak-hak asasi manusia dalam konsep hidup berbangsa dan bernegara. Sudah tentu, lahirnya gagasan tentang defnisi keadilan sosial ini merupakan hasil refeksi Soekarno tentang masa gelap sejarah bangsa Indonesia. Bangsa Indonesia telah mengalami penderitaan, penindasan, penghinaan dan penghisapan oleh penjajahan Belanda dan Jepang. Pernyataan teks di atas membuktikan bahwa Soekarno ingin mencanangkan keadilan sosial sebagai warisan dan etika bangsa Indonesia yang harus diraih. Kita hendak mendirikan suatu negara "semua buat semua”. Bukan buat satu orang, bukan buat satu golongan, baik golongan bangsawan, maupun golongan yang kaya, - tetapi "semua buat semua".

Kata "sosial" dalam prinsip kelima dari Pancasila, yaitu "Keadilan sosial bagi seluruh rakyat Indonesia", memiliki dua pengertian. Pertama, menunjuk ke dimensi sosial keadilan dalam kehidupan nasional. Keadilan sosial harus melibatkan seluruh rakyat Indonesia dan harus diterapkan dalam setiap bidang kehidupan. Ini berarti bahwa keadilan sosial tidak menjadi milik hanya satu kelompok dari orang-orang tetapi bagi seluruh masyarakat Indonesia. Kedua, mengacu pada "masyarakat", yang dapat menjadi "subjek" dan "objek" keadilan. Demi kesejahteraan nasional, rasa keadilan sosial mewajibkan masyarakat dan pemerintah untuk membagi barang dan jasa secara adil. Dalam proses ini yang lemah dan marginal harus 
dilindungi dan dibantu untuk mencapai derajat yang sah pembangunan manusia. Motivasi utama untuk menerima prinsip keadilan sosial adalah kesadaran akan hak-hak yang sama dan kewajiban semua orang Indonesia dalam menciptakan masyarakat yang didasarkan pada keadilan sosial. Untuk mencapai tujuan ini, tugas utama yang harus dicapai bersama, menjaga harmoni antara hak dan kewajiban seseorang, dan menghormati hak-hak orang lain yang harus digarisbawahi. Kebenaran Keadilan, menurut pengertian klasik ilmiah, artinya pemenuhan hakhak hidup dalam hubungan sosial satu dengan yang lain dan hubungannya dengan kewajiban pemenuhan hak-hak orang lain satu dengan orang lainnya. Kata adil dapat ditemukan dalam Prinsip atau Sila kedua : ....” yang adil dan beradab". Realitas keadilan manusia, menjadi dasar dan jiwa yang melandasi Keadilan pada prinsip kelima/Sila kelima Pancasila: "Keadilan sosial bagi seluruh rakyat Indonesia" yang harus diwujudkan dalam kehidupan sosial. Bentuk keadilan dalam masyarakat, berbangsa dan bernegara yang disebut keadilan sosial atau keadilan dalam masyarakat luas, yaitu dalam arti keadilan hidup berdampingan dengan kebaikan, hidup berdampingan dalam bentuk masyarakat dan juga hidup berdampingan dalam bentuk bangsa dan negara. Inti isi "keadilan sosial" pada prinsip kelima Pancasila, merupakan perwujudan yang terkandung dalam Proklamasi Kemerdekaan sebagaimana tercantum dalam Pembukaan UUD 1945 sesuai dengan kenyataan yang adil, artinya memenuhi segala sesuatu yang menjadi haknya dalam kaitannya hidup berdampingan dengan sesama, keadilan sosial harus ada dalam hidup dan keadilan sosial syarat mutlak dan penting dalam kehidupan yang harus ditanam di perasaan hati manusia, yaitu manusia sebagai makhluk individu dan juga sebagai makhluk sosial.

Konsep keadilan Pancasila sebagai dasar penerapan triple bottom line dengan aspek profit, people, dan planet (3P), yakni bukan hanya keuntungan (Profit) yang diorientasikan, namun juga harus mampu memberikan keadilan kepada masyarakat (People) serta adil dan menjaga kelestarian lingkungan (Planet). Adil bagi perusahaan adalah Ketika mendapatkan profit (laba) dari usahanya dengan yang sesuai dengan hasil usahanya, adil bagi planet (lingkungan) perusahaan menjaga lingkungan dalam menjalankan usahanya, sedangkan adil kepada masyarakat dapat diwujudkan antara lain kepada masyarakat adat yang telah kehilangan penghidupannya dari hutan digantikan sumber penghidupan yang sepadan sehingga masyarakat dapat hidup berdampingan secara harmonis dengan 
perusahaan. Masyarakat yang telah kehilangan hutan dan merasa terabaikan oleh pemerintah dalam memberikan ijin kepada perusahaan tanpa melihat hak adat yang dimiliki masyarakat, akan melampiaskan kemarahan kepada perusahaan. Hal ini tentunya menyebabkan kerugian bagi kedua pihak, di mana CSR diharapkan dapat mengambil peran dalam meredam konflik kedua belah pihak. Peran CSR adalah sebagai jembatan dan upaya resolusi konflik yang dilakukan korporasi terhadap komunitas lokal. CSR yang Pancasilais akan diterima di Bumi Indonesia, karena Pancasila merupakan filofis bangsa yang diciptakan oleh pendiri Bangsa dari nilai-nilai luhur Bangsa Indonesia. Paduan Pancasila dengan konsep triple bottom line dengan profit, people dan planet akan menciptakan kesejahteraan bagi bangsa ini. Dengan berpedoman pada Pancasila, negeri ini akan makmur dan keadilan akan merata dan menyentuh seluruh lapisan Masyarakat Indonesia sebagai pemilik dari Republik ini.

\section{PENUTUP}

Keberadaan korporasi di tengah masyarakat memberikan dampak secara luas terhadap kehidupan masyarakat setempat. Masyarakat dan hak adatnya telah lama ada jauh sebelum Negara Indonesia terbentuk. Keberadaan dan hak masyarakat adat dengan alasan pembangunan tergusur dengan adanya korporasi yang merenggut ketenangan hidup dan mata pencahaian mereka. Hal tersebut memicu konflik masyarakat adat dan korporasi hampir di seluruh tempat yang memiliki hak adat dalam wilayah yang di ambil korporasi. Pemikiran kritis timbul bahwa negara yang mencoba menghadirkan kesejahteraan bagi warganya sesuai dengan filosofis Pancasila kurang adil dan lebih memihak kepada korporasi yang merupakan bentuk dari kapitalisme atau kepanjangan tangan dari idealisme negara barat.

Rekonstruksi CSR berdasarkan ideologi Pancasila dan UUD 1945 sebagai strategi alternatif untuk mereduksi dampak buruk dari kegiatan bisnis korporasi dan sebagai formula dalam menyelesaikan konflik. Adil yang sebagai nilai yang terkandung dalam Pancasila dapat mereduksi kekecewaan masyarakat adat yang merasa diperlakukan tidak adil. Adil menjadi poros dari corporate social responsibility (CSR) dengan konsep triple bottom line yaitu profit, people, dan planet-nya, sehingga tercipta masyarakat sejahtera. 


\section{DAFTAR PUSTAKA}

Achwan, R., Nugroho, H., \& Prayogo, D. (2004). development analysis in Central Kalimantan. UNDP, LabSosio UI and Bappenas Overcoming violent conflict: Peace and West Kalimantan, and Madura. Jakarta

Amin, S. (1974). Accumulation on a World Scale: A Critique of the Theory of Underdevelopment. Vol.1. London, Monthly Review Press.

Bahar, Saafroedin, Kusuma, Ananda B. dan Hudawati, Nannie. Risalah Sidang Badan Penyelidik Usaha-Usaha Persiapan Kemerdekaan Indonesia (BPUPKI)-Panitia Persiapan Kemerdekaan Indonesia (PPKI), Jakarta: Sekretariat Negara Republik Indonesia, 1995.

Belkaoui, A.R. 2000. Teori Akuntansi. Edisi Pertama.Jakarta: Salemba Empat

Brewer, Anthony. (1999). Kajian Kritis Das Kapital Karl Marx. Jakarta: Teplok Press.

Burrell, G., and G. Morgan. 1979. Sociology paradigms and organizational analysis: elements of sociology of corporate life, London: Heineman Educational Books, Ltd.

Chua, W.F. (1986). Radical Developments in Accounting Thought. The Accounting Review, Vol. 61, No. 4 (Oct., 1986), pp. 601-632.

Elkington, John. "Cannibals woth Forks: The Triple Bottom Line of 21th Century Business" in Capstone Publishing, Oxford, 1997.

Juliandi A, Irfan, Manurung S. 2014. Metodologi Penelitian Bisnis: Konsep dan Aplikasi. Medan: UMSU Press.

Klonoski, R.J. (1991). Foundational considerations in the corporate social responsibility debate. Business Horizons, July-August, 9-18.

O’ Donnel. "Postmoderniesme" in Kanisius, Yogjakarta, 2009.

Prasojo, Eko. 2006. "Reformasi Rekrutmen PNS di Indonesia" dalam Eko Prasojo, et.al. 2006. Mengurai Benang Kusut Birokrasi: Upaya Memperbaiki Centang Perenang Rekrutmen PNS. Editor: Fajar Nursahid. Cetakan I. Jakarta: Piramedia

Prayogo, D. et al. (2001). Identification of social mapping and relationship between community and magma Nusantara Ltd., Pangalengan, Bandung. Research Report, Depok: LabSosio UI.

Prayogo, D. et al. (2004). Konflik antara korporasi dengan komunitas: Pengalaman beberapa industri tambang dan minyak di Indonesia. Masyarakat, 13, 64. Spicker, P. (1995). Social policy, themes and approaches. London: Prentice Hall 
Raco, Josef R. 2010. Metode Penelitian Kualitatif. Jakarta: Grasindo.

Simanjuntak, Bungaran Antonius. Arti dan Fungsi Tanah bagi Masyarakat Batak Toba, Karo, Simalungun. Jakarta: Yayasan Pustaka Obor Indonesia, 2015. Hlm.vii.

Smith, N., Craig. (2002). Corporate Social Responsibility: Not Whether, But How?" California Management Review 45,4:52-76.

Sweezy, P., M. (1964). The Theory of Capitalist Development: Principles of Marxian Political Economy. New York: Monthly Review Press.

Triyuwono, I. "Formulasi Karakter Laporan Akuntansi Syariah dengan Pendekatan Filsafat Manunggaling Kawulo Gusti (Syekh Siti Jenar)", inProsiding Simposium Nasional Sistem Ekonomi Islami II, PPBEI, Universitas Brawijaya Malang, 2004

Wolfgangstreeck, How to Study Contemporary Capitalism,European Journal of Sociology. 